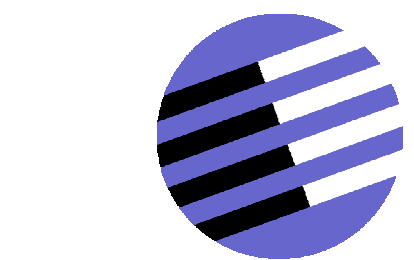

GOVERNANCE AND THE EFFICIENCY

OF ECONOMIC SYSTEMS

G ES Y

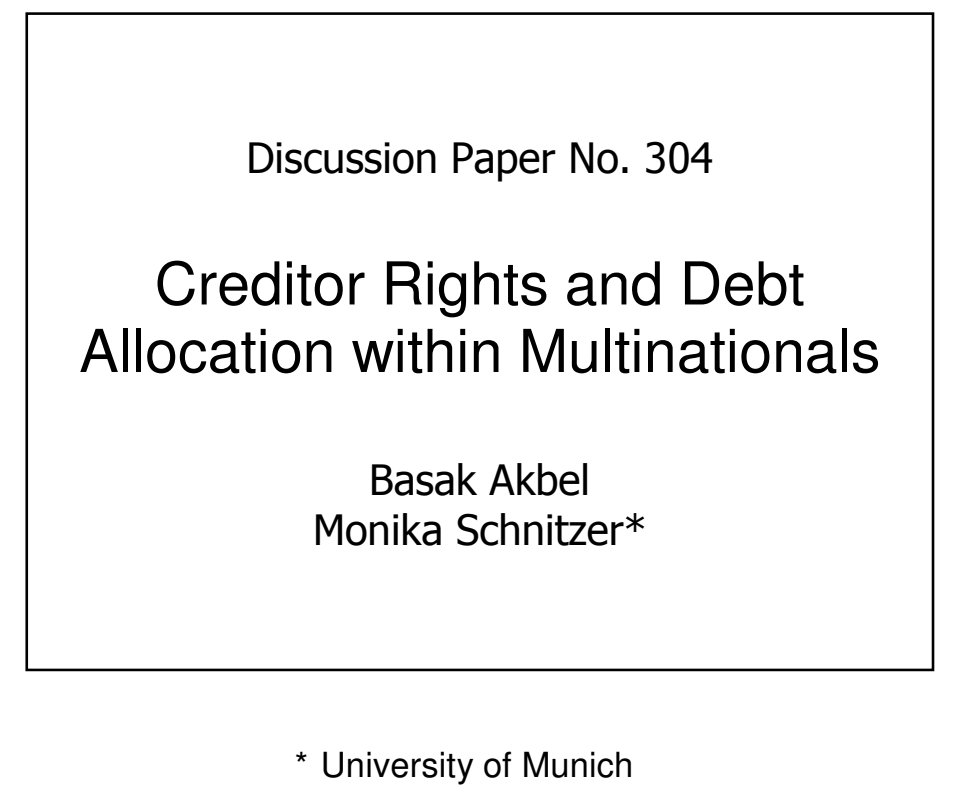

November 2009

Financial support from the Deutsche Forschungsgemeinschaft through SFB/TR 15 is gratefully acknowledged. 


\title{
Creditor Rights and Debt Allocation within
}

\author{
Multinationals
}

\author{
Basak Akbel \\ Monika Schnitzer*
}

November 2009

\begin{abstract}
We analyze the optimal debt structure of multinational corporations choosing between centralized or decentralized borrowing. We identify how this choice is affected by creditor rights and bankruptcy costs, taking into account managerial incentives and coinsurance considerations. We find that partially centralized borrowing structures are optimal with either weak or strong creditor rights. For intermediate levels of creditor rights fully decentralized (centralized) borrowing structures are optimal if managers have strong (weak) empire building tendencies. Decentralized borrowing is more attractive for companies focussing on short-term profitability. Credits are rather taken in countries with better creditor rights and more efficient insolvency systems.
\end{abstract}

JEL classification: G32, F23

Keywords: Multinational corporations, capital structure, creditor rights, coinsurance, internal capital markets

\footnotetext{
${ }^{*}$ Corresponding author: Monika Schnitzer, Department of Economics, University of Munich, Akademiestr.1/III, 80799 Munich, Germany, email: schnitzer@lrz.uni-muenchen.de. Financial support through SFB-TR 15 is gratefully acknowledged.
} 


\section{Introduction}

Multinational companies (MNCs) have a wide range of financing options when they set up a foreign subsidiary. They can rely on capital transferred from the parent company, but they can also raise local credits. How do multinational firms finance their foreign subsidiaries? To what extent do they rely on local financing and why? Empirical evidence suggests that only part of the subsidiaries is financed internally, with capital from the parent company. Furthermore, multinationals seem to choose a different financing strategy depending on where their foreign subsidiary is located. Kang et al. (2004) report that in industrial countries 29 percent of the financing of subsidiaries come from parents and 42 come from host residents, while in developing countries 45 percent of the financing come from U.S. parents and 34 percent come from host country residents.

In this paper we focus on one particular aspect of a multinational's financing decision: the credit financing. ${ }^{1}$ If (at least) part of the financing has to be done through credits, the question arises whether these should be raised locally in the foreign subsidiary's host country or via the parent company. The aim of our paper is to determine the optimal debt allocation within a multinational corporation. For this purpose we develop a model of multinational borrowing that explicitly considers agency problems in internal capital markets, the existence of bankruptcy costs and the role of creditor rights.

In our model the trade-off between decentralized (local) and centralized (parent) debt financing is driven by two main effects, the incentive and the coinsurance effect. Centralizing the borrowing structure allows the multinational corporation to realize a so-called coinsurance effect. $^{2}$ In this case the CEO of a MNC can use the net profits of all its

\footnotetext{
${ }^{1}$ Note that the focus of this paper is on the location choice of borrowing. How the choice of debt vs. equity is determined for multinational corporations is studied elsewhere (see Kesternich and Schnitzer (2007)).

${ }^{2}$ This coinsurance capacity has also been recognized by a different strand of the literature dealing with the boundary of the firm and the optimality of conglomeration. Lewellen (1971) was among the first to focus on this coinsurance aspect in view of the large mergers wave in the US of the 1960s. Even though this strand of the literature has thoroughly investigated the differences between stand-alone firms and conglomerates (e.g. Inderst and Müller (2003), Berkovitch et al. (2006), Li and Li (1996) and FaureGrimaud and Inderst (2005)), the authors mainly focus on the effects on investments in internal capital markets and the valuation of conglomerates. These articles neither consider the debt allocation within
} 
subsidiaries to repay debt and avoid costly bankruptcy. Only if the sum of net profits is not sufficient to cover all debt repayments, bankruptcy occurs. Thus, one subsidiary "coinsures" another subsidiary and bankruptcy becomes less likely. This is the positive effect associated with debt centralization.

However, debt centralization also entails negative incentive effects. These arise because the coinsurance of the subsidiaries attenuates the disciplining effect of debt. Consider a multinational with two subsidiaries $F$ and $H$. If, say, the manager of subsidiary $F$ borrows locally, he is directly liable to his debtors. This gives him strong immediate incentives to work hard and avoid the bankruptcy of his subsidiary - at least if he enjoys private benefits of control and does not want to lose his job (Aghion and Bolton (1992)). ${ }^{3}$

Centralizing the borrowing for subsidiary $F$ weakens manager $F$ 's incentives because it reduces the direct link between his success and the liquidation of his subsidiary: Even if he fails, subsidiary $F$ will not be liquidated as long as subsidiary $H$ is successful because he "is coinsured" by subsidiary $H$.

Similarly, centralizing the borrowing for subsidiary $H$, thus "coinsuring" subsidiary $H$ entails negative incentive effects for the subsidiary manager $F$ as well. Now, internal capital market considerations come into play: If subsidiary $H$ is coinsured and fails but manager $F$ is successful, the profits generated by manager $F$ are used to meet the debt repayments of subsidiary $H$. As managers are typically interested in having large empires, taking away these funds reduces a manager's benefits and hence his incentives. This is the downside of reallocating funds within internal capital markets (see for example Brusco and Panunzi (2005)). To summarize, both "being coinsured" by and "coinsuring" the other subsidiary entail adverse incentive effects. These negative incentive effects countervail the positive risk-reducing effect of coinsurance.

the multi-entity firm nor the possibility of employing mixed borrowing structures nor the relevance of creditor rights explicitly.

${ }^{3}$ The disciplining effect of bankruptcy is especially important in countries in which it is difficult or very costly to write contracts with subsidiary managers about a performance-based dismissal. For example, this might be the case in countries with very strong employer rights, like Germany and other Western European countries. Furthermore, managerial entrenchment might reduce the credibility of contract enforcement. 
The trade-off between coinsurance and incentive effects differs for various host countries depending on the strength of creditor rights. ${ }^{4}$ Stronger creditor rights imply more control rights for the creditor in case of insolvency. As creditors are interested in liquidating insolvent firms, the liquidation of unsuccessful firms becomes more likely when creditor rights are stronger. ${ }^{5}$ When creditor rights are weak, the threat of liquidation in case of insolvency and hence the disciplining effect of debt is less present than with strong creditor rights. This affects the overall trade-off.

We determine the optimal debt structure depending on firm characteristics and the specific legal and institutional settings. In the first part of our analysis we disregard differences in the legal environment of host and home countries. In the second part of the paper we introduce these differences and derive how they affect the optimal borrowing structure.

Our main findings are as follows: For MNCs operating in countries with very weak or very strong creditor rights, mixed borrowing structures are optimal. A "mixed borrowing structure" indicates a borrowing structure with centralized borrowing for one subsidiary and decentralized borrowing for the other subsidiary. The optimality of the borrowing structure for intermediate ranges of creditor rights depends on managerial incentives: If managerial empire-building tendencies are weak, a fully centralized borrowing structure is optimal. If empire-building tendencies are strong, a fully decentralized borrowing structure is optimal because it becomes more attractive to provide incentives.

Stronger creditor rights increase the attractiveness of substituting parental borrowing

\footnotetext{
${ }^{4}$ In practice insolvency regimes and bankruptcy procedures are very complex. For example, often, an insolvent firm does not have to file for bankruptcy but can reach an out-of-court settlement with its creditors. Even if an insolvent firm is declared bankrupt, it can still be either liquidated or reorganized. Overall, there are a multitude of possible outcomes for an insolvent firm depending on the specific institutional environment and bankruptcy legislation. It is beyond the scope of our paper to include the multitude of insolvency regimes. We only focus on the link between creditor rights and the probability of liquidation in case of insolvency.

${ }^{5}$ See also Dewatripont and Tirole (1994). We do not know of any empirical paper directly investigating the relationship between creditor rights and firm liquidation. However, a recent paper by Claessens and Klapper (2005) finds a positive relationship between the strength of creditor rights and bankruptcy. Based on the plausible assumption that more bankruptcy filings are associated with more liquidation, this paper provides support for our modeling. See also Acharya et al. (2005) for the positive relationship between creditor orientation and liquidation. This aspect requires further investigation.
} 
with local debt in the foreign affiliate's country. Furthermore, we find that, due to agency problems, weak creditor rights are associated with higher probability of bankruptcy and higher interest rates for foreign affiliates' local borrowing. Higher bankruptcy costs increase the attractiveness of centralized borrowing.

If the two countries in which the multinational operates differ with respect to bankruptcy costs, the CEO prefers to borrow in the country with a more efficient bankruptcy system. Differences in creditor rights do not have any direct effect on expected profits under any of the borrowing structures. However, as they affect the disciplining effect of debt, they influence managerial incentives and indirectly expected profits. More specifically, weaker creditor rights in the foreign country decrease the attractiveness of a (partially) decentralized borrowing structure.

The remainder of this paper is structured as follows: Section ?? gives an overview of the related literature. Section ?? lays out the set-up and basic mechanisms of our model. In section ?? we derive the equilibrium outcome and optimality conditions in a national setting. Section ?? analyzes the comparative statics and introduces differences in the legal environment between the affiliate's and the parental country. Section ?? highlights the empirical findings of our model. Section ?? concludes.

\section{Related Literature}

The borrowing decision of multinational corporations (MNCs) has attracted increasing attention over the last years. A major focus is on the comparison between multinational corporations and national firms on an aggregated level. Several authors investigate whether the overall leverage of MNCs is higher or lower as compared to national corporations (see for example Doukas and Pantzalis (2003), Fatemi (1988), Lee and Kwok (1988), Mittoo and Zhang (2005) and Burgman (1996)). Another strand of the multinational finance literature explicitly considers the determinants of foreign affiliates' borrowing structures. Even though these papers account for the possibility of profit shifting within multination- 
als and the opportunity to substitute external with internal funds, the primary focus is on tax issues (Hodder and Senbet (1990), Chowdhry and Nanda (1994), Chowdhry and Coval (1998) and Huizinga et al. (2008)). Empirical evidence suggests that a major determinant of the multinational's and its subsidiaries' borrowing structure is the institutional and legal environment of the host country (Errunza (1979)). The relevance of political risk as a determinant has been investigated extensively over the last years. ${ }^{6}$

The only paper explicitly considering the effect of host country creditor rights on the leverage of multinational affiliates is Desai et al. (2004). The authors find a positive relationship between creditor rights and local borrowing of the affiliate. Their second finding of a negative relationship between creditor rights and interest rates is confirmed by $\mathrm{Ag}$ garwal and Kyaw (2004), who also investigate the effects of the host country environment on the capital structure of MNC affiliates. Similarly, Laeven and Majnoni (2005) find that judicial efficiency is negatively correlated with interest rate spreads across countries. Finally, Kang et al. (2004) identify a positive relationship between the degree of financial market development - which, as other authors show, is closely related to creditor rights and their enforcement - and the extend of local borrowing for multinational affiliates. The findings of our model are confirmed by these empirical studies. However, overall there is still very little work done on the effect of creditor rights on multinational capital structure.

In contrast, there is a large and growing body of mainly empirical literature on law and finance. Starting with La Porta et al. $(1997,1998)$ this strand of the literature provides ample evidence of the central role legal institutions and creditor rights play for capital markets. Both laws and their enforcement matter in credit markets (Safavian and Sharma (2007)). Demirguc-Kunt and Maksimovic (1998, 1999) show that in countries with more efficient legal systems, more firms use long-term external finance (1998) and firms do use

\footnotetext{
${ }^{6}$ Aggarwal and Kyaw (2004) identify that for US multinational affiliates among others low political risks were associated with high external debt ratios. Hooper (2002) and Desai et al. (2008), on the other hand, find significantly higher (local) debt ratios for affiliates in politically riskier countries. Kesternich and Schnitzer (2007) show, theoretically and empirically, how different forms of political risks affect the multinational capital structure.
} 
more long-term external debt relative to assets (1999). Similarly, also Giannetti (2003) finds that firms in countries with better creditor protection have higher leverage. Safavian and Sharma (2007) provide evidence on how (enforced) creditor rights allow for a better access to bank credit.

The only other theoretical paper which incorporates creditor rights in a multinational finance model is Noe (2000). The author shows how, in a setting with differences in the creditor rights between the parental country and the host country of the subsidiary, bargaining over the debt in case of bankruptcy determines the optimal debt allocation within a multinational. Similar to our work, the author recognizes the trade-off the CEO of a multinational faces between reducing the occurrence of costly bankruptcy and agency costs associated with weak creditor rights and finds a positive relationship between local borrowing and the strength of creditor rights in the host country. However, we can show how creditor rights influence the optimal borrowing decision even in the absence of differences between the legal setting of both countries - as it is the case for nationally operating business groups as well as multinationals operating in countries with similar legal environments. Furthermore, we take our analysis one step further, as we do not only focus on the borrowing decision of a single subsidiary but take into account the existence of internal capital markets. As we show in our analysis, a comprehensive view of the multinational with all its subsidiaries is essential to understanding the borrowing decision of and debt allocation within a multinational corporation. The reason lies in the feedback effects on managerial incentives, which were identified by the literature on internal capital markets. ${ }^{7}$

Starting with Gertner et al. (1994) and Stein (1997) the literature on internal capital markets did pioneering work in corporate finance by identifying incentive problems within large corporations. Rajan et al. (2000) find evidence for inefficient internal crosssubsidization between divisions. Brusco and Panunzi (2005), Gautier and Heider (2002), Inderst and Laux (2005) and Inderst and Müller (2003) all develop models with man-

\footnotetext{
${ }^{7}$ A good survey of the internal capital markets literature is given by Stein (2003).
} 
agerial incentives of empire-building, in which they highlight adverse incentive effects associated with the reallocation of internally generated funds. Even though their focus is typically on the trade-off between efficiency and incentive aspects of "winner-picking", the underlying incentive mechanisms are the same as for our modeling of the incentive effects associated with coinsuring the other subsidiary. Inderst and Müller (2003) are the only ones who do not only focus on the reallocation of existing internal funds but include the effects on external funding and account for the coinsurance effect of conglomeration.

And finally, a separate but related strand of the corporate finance literature considers the financing of nationally operating business groups. The focus of this literature is mainly on corporate governance issues and the explanation of concentrated, often pyramidal and family controlled ownership structures, while taking into account different legal environments. However, there are a few papers explicitly investigating the debt structure within business groups. Bianco and Nicodano (2006) acknowledge the richer debt structure choice of business groups as compared to stand-alone firms and the relevance of limited liability in determining the optimal debt allocation within business groups. Finally, Gopalan et al. (2007) find evidence for cross-subsidization after weak performance and lower bankruptcy rates for group affiliates as compared to stand-alone firms.

\section{The Model}

Consider a multinational corporation (MNC) that consists of a non-operating parent company and two legally independent subsidiaries. All units are run by risk-neutral managers. While one of the subsidiaries $(H)$ is located in the home country of the parent company, the other subsidiary $(F)$ operates in a foreign country. Each subsidiary manager has the opportunity to invest into a project. ${ }^{8}$

Each investment project yields a return of $X$ in case of success and zero otherwise. Project returns are uncorrelated. The probability of success for the investment project in the foreign subsidiary $F$ is directly determined by the effort level of the subsidiary

\footnotetext{
${ }^{8}$ In the following analysis, we only consider investment projects with a positive net present value.
} 
manager. In particular, if the manager chooses the effort level $q_{F}$, the corresponding probability of success is $q_{F}$. As effort is costly, the manager chooses the probability of success $q_{F} \in[0,1]$ that maximizes his utility, given the borrowing structure of the multinational corporation. We will discuss the underlying managerial incentives in more detail below. To keep the analysis concise, we focus on the incentives of manager $F$ in the foreign country and therefore fix the probability of success for the investment project in subsidiary $H$ at an exogenously given level of $q_{H}$ with $q_{H} \in[0,1] .{ }^{9}$ By introducing this asymmetry between the two subsidiaries, we also take into account in a stylized way the empirical finding that monitoring becomes more difficult with distance. ${ }^{10}$

Both projects generate further profits beyond the first period. These additional profits are identical for both subsidiaries and denoted by $Z$. $Z$ can be interpreted as the sum of discounted future profits of a subsidiary and it is independent of managerial effort and the first period outcome.

\section{Borrowing Structures and Bankruptcy}

Financing an investment project requires a certain amount of external debt $D$. Outside investors provide the necessary funds. The market interest rate is normalized to zero, so the investors' opportunity cost is zero. Investors are risk-neutral and fully competitive. They will therefore realize expected profits of zero. Interest rates for the investment projects are determined endogenously. The manager of the parent company, i.e. the CEO of the multinational firm, decides on the debt allocation within the MNC. The CEO maximizes total expected profits for the multinational firm. For each subsidiary he decides whether the borrowing is undertaken centrally by the parent company or decentrally by the subsidiary. Thus, he can choose among the following four borrowing structures:

1. A fully decentralized debt structure, with decentralized borrowing in both subsidiaries, denoted by $d d$.

\footnotetext{
${ }^{9}$ In doing so we follow Boot and Schmeits (2000) in their main analysis, who in a similar set-up investigate the effects of coinsurance and incentives on the optimality of conglomeration.

${ }^{10}$ See Doukas and Pantzalis (2003) and Wright et al. (2002). In a similar vein, Burgman (1996) finds that MNCs have higher agency costs as compared to national corporations.
} 


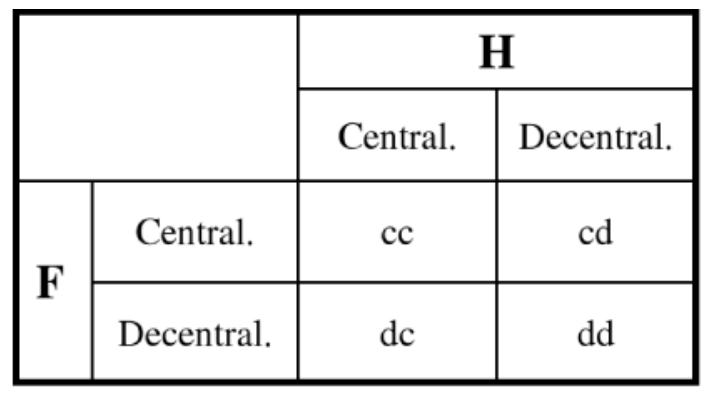

Figure 1: Overview Borrowing Structures

2. A mixed debt structure, with decentralized borrowing in subsidiary $F$ and centralized borrowing for subsidiary $H$, denoted by $d c$.

3. A mixed debt structure with centralized borrowing for subsidiary $F$ and decentralized borrowing in subsidiary $H$, denoted by $c d$.

4. A fully centralized debt structure, with centralized borrowing for both subsidiaries, denoted by $c c$. In this case, the CEO borrows the total amount of $2 D$ from a single creditor. $^{11}$

Figure ?? gives an overview of these debt structures. ${ }^{12}$ The first letter always indicates the borrowing in the foreign subsidiary $F$, whereas the second letter refers to the borrowing for subsidiary $H$; $c$ stands for centralized borrowing by the parent company and $d$ for decentralized borrowing by the subsidiary itself.

If debt repayments cannot be met, the borrowing unit is insolvent and a bankruptcy process is initiated. ${ }^{13}$ Initiating a bankruptcy process entails costs that reduce the future value of the corresponding subsidiary to $\alpha Z, \alpha \in[0,1]$. These bankruptcy costs are

\footnotetext{
${ }^{11}$ Borrowing from a single investor is in the interest of the CEO because it allows him to credibly convey the information to the creditor that the debt structure is completely centralized. It furthermore is a reasonable presumption if we consider transaction cost motives.

${ }^{12}$ The question might arise, why the CEO could not decide to mix centralized and decentralized borrowing for each subsidiary. In fact, the model does not preclude these kind debt structures but rather focuses in a stylized way on the effects of a sufficiently high level of local borrowing. Thus, one can think about the necessary amount of external debt, $D$, as the crucial amount of (additional) borrowing, which would induce difficulties in payment in case of failure.

${ }^{13}$ In the following we use the expressions insolvency and bankruptcy synonymously in referring to the situation that a debtor is not able to meet its debt repayments. Hence, 'bankruptcy process' is meant in a comprehensive way including also possible out of court settlements.
} 
independent of whether the insolvent borrowing unit is continued or liquidated. ${ }^{14}$ Thus, we refrain from considering further value-destroying inefficiencies in case of liquidation of the firm. These further costs would complicate the analysis without changing the qualitative results of our model.

In order to capture the effect of creditor rights on the bankruptcy process, we introduce a parameter $p \in[0,1]$. The parameter $p$ reflects the probability of liquidation for the borrowing unit in case of insolvency. If liquidated, the assets of the subsidiary, i.e. the future value $\alpha Z$, are transferred to the debtor. With the probability of $(1-p)$, liquidation does not take place. In this case debtors obtain nothing and $\alpha Z$ remains within the corresponding subsidiary. Creditor rights affect the probability of liquidation $p$ insofar as a stronger creditor-orientation typically leads to a relatively high probability of liquidation $p$. Conversely, in countries with weak creditor rights and/or a more debtor-oriented legal environment the liquidation of an insolvent firm is less probable, resulting in a lower value for $p .^{15}$

We start by analyzing a set-up that does not allow for differences in the legal setting, in particular for the parameters $\alpha$ and $p$, between the two countries. This setting applies to purely nationally operating business groups as well as multinationals operating in countries with similar legal environments like Germany and Italy. However, differences in the legal environment introduce further effects on the optimality of the debt structure. These effects, which are especially present in multinational corporations operating in very different countries like Germany and India, will be investigated in section ??.

\footnotetext{
${ }^{14}$ These might include direct bankruptcy costs, like filing and administrative costs but especially consist of indirect bankruptcy costs like the loss of future business and profits due to high insecurity and bad reputation associated with the rumors about the corporation's insolvency independent of whether it is actually declared bankrupt. Due to the relevance of missed profits, we prefer to consider proportional bankruptcy costs $(1-\alpha) Z$ in our model. However, our results also hold in a setting with additive bankruptcy costs in the form of $-C$. For empirical research on the costs of bankruptcy see also Altman (1984). As also Djankov et al. (2006) find in a case study, bankruptcy costs are c.p. higher, thus $\alpha$ lower, the less developed the country is.

${ }^{15}$ In a simplified way we could think about the difference between a creditor-oriented legal environment like in Germany and a typically more debtor-oriented legal system like the US system. For empirical evidence on this relationship see for example Claessens and Klapper (2005). Even though they only investigate the relationship between filing for bankruptcy and creditor rights, their finding of a positive relationship gives suggestive support for our modeling. See also Acharya et al. (2005) for the positive relationship between creditor orientation and liquidation.
} 


\section{The Coinsurance Effect}

To capture the effect of coinsurance in our model, we make the following assumption: ${ }^{16}$

Assumption 1 The return $X$, which a single investment project generates if successful, is high enough to cover the debt repayments of both investment projects whenever needed.

Assumption ?? ensures that debt repayments are feasible. Furthermore, it ensures that in case of (partially) centralized borrowing the parent company is able to meet both debt repayments and thus avoid a costly bankruptcy process as long as at least one of the subsidiaries is successful. ${ }^{17}$ This introduces the possibility of coinsurance: Centralizing the borrowing structure c.p. reduces the occurrence of costly bankruptcy. To see this we consider the different borrowing structures in more detail.

1. Fully decentralized debt structure $(d d)$

In this case, each subsidiary manager borrows on his own. For each subsidiary the project can either be successful and debt can be repaid, or it can be unsuccessful and the insolvency of the subsidiary has to be declared. ${ }^{18}$ Note that this can only be an equilibrium outcome if the parent company does not have any incentives to bailout the subsidiary concerned. It is the case if the following condition holds: $Z-D R_{k}^{i j} \leq$ $(1-p) \alpha Z$, with $i, j \in\{c ; d\}, k \in\{F, H\}$, and $R_{k}^{i j}$ as the equilibirum interest rate. This condition can be rearranged to $D R_{k}^{i j} \geq Z[1-(1-p) \alpha]$. Throughout the paper we only consider cases for which this condition holds.

\section{2./3. Mixed debt structures $(d c, c d)$}

\footnotetext{
${ }^{16}$ For keeping the exposition of our model as simple as possible, the formal delineation of this assumption is only introduced when needed in the further analysis.

${ }^{17}$ This is in line with empirical evidence on inefficient cross-subsidization in business groups (Gopalan et al. (2007)).

${ }^{18}$ This can only be an equilibrium outcome if the parent company does not have any incentives to bailout the subsidiary concerned. This is the case if the following condition holds: $Z-D R_{k}^{i j} \leq(1-p) \alpha Z$, with $i, j \in\{c ; d\}, k \in\{F, H\}$, and $R_{k}^{i j}$ as the equilibirum interest rate. This can be rearranged to $D R_{k}^{i j} \geq Z[1-(1-p) \alpha]$. The condition states that the necessary debt repayments have to be larger than the increase in the expected future value for the MNC if the local debt is repayed. In case of debt repayment, the future value within the MNC would be $Z$ with certainty. In case of insolvency, there is a chance that the subsidiary will not be liquidated resulting in the expected future value of $(1-p) \alpha Z$ at the end of $t=1$. The cost of debt repayment is $D R_{k}^{i j}$.
} 
Consider $d c$ first. Under $d c$ subsidiary $F$ (in the foreign country) borrows locally whereas the parent company borrows on behalf of subsidiary $H$ (in the parental country). A bankruptcy process will be initiated for subsidiary $F$ if $F^{\prime} s$ project fails. However, subsidiary $H$ benefits from the coinsurance by subsidiary $F$ : Even if $H^{\prime} s$ project fails, the parent company is able to repay the debt, as long as subsidiary $F$ is successful. ${ }^{19}$ Only if $F^{\prime} s$ project fails as well, the parent company has to declare bankruptcy. The reasoning for $c d$ follows the same lines.

4. Fully centralized debt structure $(c c)$

If the borrowing is completely centralized, both subsidiaries coinsure each other and the parent company has to declare bankruptcy only if both fail simultaneously. In this case, the whole MNC is liquidated with the probability $p$.

Thus, for given effort levels, centralizing the borrowing structure reduces the occurence of bankruptcy.

\section{MANAGERIAL INCENTIVES}

We now turn to managerial incentives. The manager of subsidiary $F$ derives private benefits of control. These "classical" managerial benefits of control are denoted by $M \geq 0$ and reflect the psychic benefits of running the subsidiary, having a prestigious job, etc. (Aghion and Bolton (1992)). The manager can enjoy $M$ as long as he is the manager of the subsidiary. This is definitely the case if his investment project is successful. However, even if his project fails, he may be able to enjoy these benefits: Either because he is helped-out by subsidiary $H$ or because weak creditor rights prevent the liquidation of subsidiary $F$.

Furthermore, the manager's private benefits increase with the resources under his control, i.e. the manager enjoys empire-building. ${ }^{20}$ To capture this effect, we introduce

\footnotetext{
${ }^{19}$ We implicitly assume that the funds can be frictionless passed on to the parent company if needed.

${ }^{20}$ Note that in the following we use the term "empire-building" slightly different from other authors. While with "empire-building" some previous papers referred to the resulting problem of inefficient overinvestment, we focus on the underlying managerial incentives. Throughout our paper "empire-building" refers to the interest of the manager in having more assets under management. Even though we exclude
} 
the benefit variable, $E \geq 0$. The manager enjoys $E$, whenever he is successful and does not have to bailout subsidiary $H .^{21}$

Finally, we assume that effort is costly for the manager. Effort costs are captured by the following quadratic cost function $\frac{1}{2} q_{F}^{2} \cdot{ }^{22}$

The manager's expected utility for the different borrowing structures are given by the following functions:

$$
\begin{aligned}
E U(d d)= & q_{F}(M+E)+\left(1-q_{F}\right)(1-p) M-\frac{1}{2}\left(q_{F}\right)^{2}, \\
E U(d c)= & q_{F} q_{H}(M+E)+\left[q_{F}\left(1-q_{H}\right)+\left(1-q_{F}\right)(1-p)\right] M-\frac{1}{2}\left(q_{F}\right)^{2}, \\
E U(c d)= & q_{F}(M+E)+\left\{\left(1-q_{F}\right)\left[q_{H}+\left(1-q_{H}\right)(1-p)\right]\right\} M-\frac{1}{2}\left(q_{F}\right)^{2}, \\
E U(c c)= & q_{F} q_{H}(M+E)+ \\
& \left\{q_{F}\left(1-q_{H}\right)+\left(1-q_{F}\right)\left[q_{H}+\left(1-q_{H}\right)(1-p)\right]\right\} M-\frac{1}{2}\left(q_{F}\right)^{2} .
\end{aligned}
$$

The first two terms capture the expected managerial benefits and the last term the monitoring costs. Note that the manager's wage is normalized to his outside option of zero. This is a reference case reflecting the problem that managers can not be given perfect incentives by wage contracts alone in the presence of incomplete contracts. ${ }^{23}$ We expect cultural and geographical distance between the parent company and a foreign subsidiary to aggravate the problem of contractual incompleteness, making it particularly relevant in the present context of a multinational corporation. Furthermore, given that external contracts are enforceable, the CEO is not able to influence the continuation decision for an insolvent subsidiary with decentralized borrowing. ${ }^{24}$ Therefore, the use of external

overinvestment in our model, we show that these managerial preferences induce additional inefficiencies in a conglomerate setting.

${ }^{21}$ If the borrowing for subsidiary $H$ is undertaken centrally and subsidiary $H$ fails, the profits generated by the investment project in subsidiary $F$ (in case of success) are used by the parent company to meet the debt repayments of subsidiary $H$. In this case, the manager of subsidiary $F$ is not able to enjoy $E$, even though he is successful.

${ }^{22}$ This simple functional form for the effort costs allow us to keep the analysis explicit. However, we could generalize the cost function without loss of generality as long as it is increasing and convex in $q_{F}$.

${ }^{23}$ See for example Dewatripont and Tirole (1994).

${ }^{24}$ Even if the CEO could avoid insolvency for a decentrally borrowing subsidiary as long as the other subsidiary is successful, this is now costly. As discussed above, we only consider cases in which these 
debt is also a credible commitment device even with an entrenched subsidiary manager.

\section{Expected Profits}

We now derive expected profits for the MNC under the different borrowing structures. As shown in the Appendix, these are given by

$$
\begin{aligned}
& E \pi(d d)=\left(q_{F}^{d d}+q_{H}\right) X-2 D+\left[2-\left(2-q_{F}^{d d}-q_{H}\right)(1-\alpha)\right] Z, \\
& E \pi(d c)=\left(q_{F}^{d c}+q_{H}\right) X-2 D+\left[2-\left(2-q_{H}\right)\left(1-q_{F}^{d c}\right)(1-\alpha)\right] Z, \\
& E \pi(c d)=\left(q_{F}^{c d}+q_{H}\right) X-2 D+\left[2-\left(1-q_{H}\right)\left(2-q_{F}^{c d}\right)(1-\alpha)\right] Z, \\
& E \pi(c c)=\left(q_{F}^{c c}+q_{H}\right) X-2 D+\left[2-2\left(1-q_{F}^{c c}\right)\left(1-q_{H}\right)(1-\alpha)\right] Z .
\end{aligned}
$$

All four expected profit functions have the same structure:

The first term reflects first period expected returns from the investment. They depend on the probabilities of success, and are higher with higher managerial effort levels and thus probabilities of success for subsidiary $F . q_{F}^{d d}, q_{F}^{d c}, q_{F}^{c d}$ and $q_{F}^{c c}$ denote the optimal effort levels under the different borrowing structures and will be derived in section ??.

The second term is the total amount of investment needed, reflecting the real economic costs of the investment projects, which is $D$ for each subsidiary and independent of managerial effort.

The last term reflects the expected second period profits of the investment projects. Recall that $2 Z$ is the value of second period profits in the absence of bankruptcy costs. As bankruptcy reduces the second period profits of a subsidiary to $\alpha Z$, the resulting economic loss in case of bankruptcy is $(1-\alpha) Z$ per subsidiary. For each borrowing structure this economic loss is multiplied with the corresponding probability of bankruptcy. For example, under a fully decentralized borrowing structure each subsidiary will declare bankruptcy with the probability $\left(1-q_{i}\right)$ with $i=F, H$, resulting in the overall expected bankruptcy loss of $\left(2-q_{F}^{d d}-q_{H}\right)(1-\alpha) Z$. Similarly expected bankruptcy costs can be derived for all four settings.

costs are prohibitively high and the CEO has no incentive to bailout the subsidiary. 


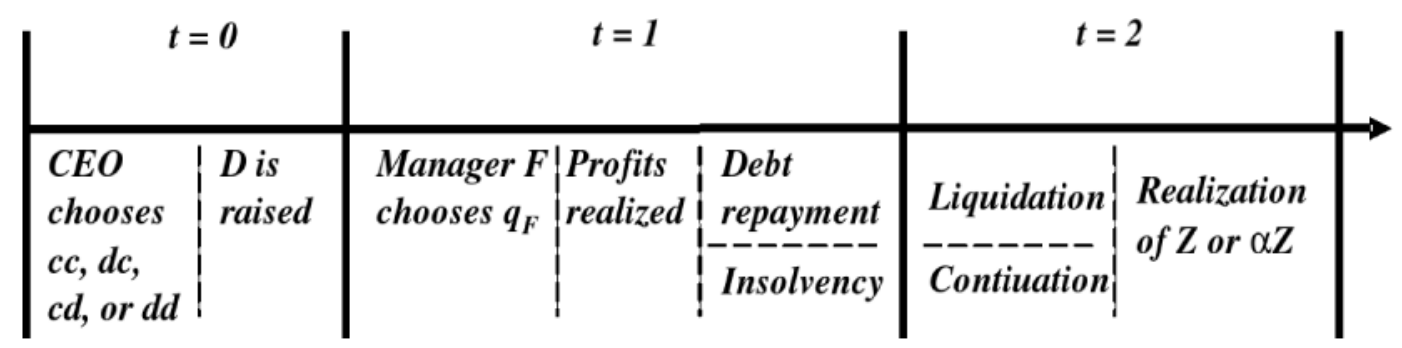

Figure 2: Time Structure

The differences between the four borrowing structures are driven by the coinsurance effect and managerial incentives. Apart from these two effects the choice of the borrowing structure does not influence expected profits. In particular, as investors make zero expected profits, interest rates are irrelevant for ex-ante expected profits.

\section{The Time Structure}

In period $t=0$, the $\mathrm{CEO}$ of the multinational corporation decides on the debt structure of the MNC and borrowing is undertaken. In the beginning of period $t=1$, the manager of subsidiary $F$ in the foreign country decides on his effort level. At the end of this period, project returns are realized and debt is repaid if possible. If a borrowing unit is insolvent at this stage, the corresponding subsidiary will be liquidated at the beginning of $t=2$ with the probability of $p$. At the end of period $t=2$, future firm values are realized and the game ends. The time structure of the model is summarized in figure ??.

\section{Equilibrium Outcome of the Model}

\subsection{Optimal Managerial Effort Level}

To solve the model, we first derive the optimal managerial effort level under the different borrowing structures. The optimization problem of the manager of the foreign subsidiary 
$F$ is:

$$
\begin{gathered}
\underset{q_{F}}{\operatorname{Max} E U^{i j}\left(q_{F}\right)} \\
\text { s.t. } 0 \leq q_{F} \leq 1,
\end{gathered}
$$

with $i, j \in\{c ; d\}$. Again, $i$ refers to subsidiary $F$ while $j$ relates to subsidiary $H$. Solving this optimization problem for all four debt structures yields the optimal managerial effort levels and hence probabilities of success for subsidiary $F{ }^{25}$ The internal solutions for the different borrowing structures are given by

$$
\begin{aligned}
q_{F}^{d d} & =p M+E, \\
q_{F}^{d c} & =p M+q_{H} E, \\
q_{F}^{c d} & =\left(1-q_{H}\right) p M+E, \\
q_{F}^{c c} & =\left(1-q_{H}\right) p M+q_{H} E .
\end{aligned}
$$

By comparing these probabilities of success, we derive Proposition ??.

Proposition 1 The more centralized the debt structure, the lower is c.p. the probability of success for subsidiary F. In particular:
1) $q_{F}^{d d} \geq q_{F}^{d c} \geq q_{F}^{c d} \geq q_{F}^{c c}$ if $\frac{p M}{E} \geq \frac{\left(1-q_{H}\right)}{q_{H}}$,
2) $q_{F}^{d d} \geq q_{F}^{c d} \geq q_{F}^{d c} \geq q_{F}^{c c}$ if $\frac{p M}{E}<\frac{\left(1-q_{H}\right)}{q_{H}}$.

Proof: Straightforward by comparing the optimal effort levels $q_{F}^{i j}$ with $i, j \in\{c ; d\}$.

The underlying intuition is the following: Managerial incentives and thus effort levels are driven by benefits of control (given by the first term of the optimal effort levels) and benefits of empire-building (given by the second term of the optimal effort levels). Being coinsured by subsidiary $H$ reduces manager $F^{\prime}$ s optimal effort level, as manager

\footnotetext{
${ }^{25}$ Differentiating with respect to $q_{F}$ and with $\frac{\partial^{2} E U^{i j}}{\partial q_{F}^{2}}<0 \forall i, j=c, d$ yields these internal solutions for the optimal effort level. Potential corner solutions are analyzed further down in Corollary ??.
} 
$F$ anticipates a potential bailout by $H$. This effect relates to the disciplining effect of debt (Grossman and Hart (1982), Hart and Moore (1995)), which is stronger with local borrowing. Similarly, coinsuring subsidiary $H$ reduces $F^{\prime}$ s effort: $F$ anticipates that even if he is successful, he may not be able to keep the additionally generated funds in his subsidiary but have to bailout subsidiary $H$. This effect is in the vein of the negative incentive effects associated with the reallocation of funds in internal capital markets. If we now compare the different borrowing structures, the results of Proposition ?? become clear:

Under a fully decentralized structure $d d$ neither subsidiary $F$ nor subsidiary $H$ are coinsured, so none of the adverse incentive effects is present. The manager chooses the highest effort level $q_{F}^{d d}$. Under a fully centralized structure $c c$ both of the subsidiaries are coinsured and both adverse incentive effects are present. Thus, the manager chooses the lowest effort level $q_{F}^{c c}$. Under the mixed borrowing structures $d c$ and $c d$ only one of the two adverse incentive effects of coinsuring or of being coinsured is present. The ordering between the two mixed structures is not conclusive. Whether the borrowing structure $d c$ or $c d$ is associated with a higher effort level depends on the relative strength of the two incentive effects. The stronger the effective disciplining effect of bankruptcy $p M$ as compared to the managerial empire-building tendencies $E$, and the lower the probability of success for subsidiary $H$, i.e. $q_{H}$, the stronger are the incentives under $d c$ as compared to $c d$ : With higher values for $p M$, the incentives from decentralizing the borrowing for subsidiary $F$ are very valuable, while with lower values for $E$, the loss in incentives by decentralizing $H$ are less severe. Similarly, a high value of $q_{H}$ reduces the disadvantage of centralizing the borrowing for subsidiary $H$ while it reinforces the disadvantage of centralizing the debt for subsidiary $F{ }^{26}$

Finally, note that the optimal effort levels depend on the prevailing creditor rights $p$. As $p$ reflects the threat of liquidation in case of bankruptcy, stronger creditor rights, i.e.

\footnotetext{
${ }^{26}$ The low probability of failure for subsidiary $H\left(1-q_{H}\right)$ makes it less probable that subsidiary $F$ will have to bailout subsidiary $H$ in case of coinsurance of $H$. However, the manager of subsidiary $F$ can comfortably rely on being bailed out by subsidiary $H$, in case of coinsurance of subsidiary $F$.
} 
higher values of $p$, induce higher effort levels. With strong creditor rights, the manager of subsidiary $F$ knows that whenever a bankruptcy process is initiated the probability of remaining the manager of subsidiary $F$ is small. This gives him a strong incentive to exert high effort and avoid bankruptcy. This effect is strongest for borrowing structures with decentralized debt in subsidiary $F$.

\subsection{Optimal Borrowing Structure and Creditor Rights}

As we have seen in section ??, centralizing the borrowing structure allows the CEO of the multinational corporation to reallocate internal funds in order to c.p. reduce the occurrence of bankruptcy and hence expected bankruptcy costs. However, coinsuring the subsidiaries entails adverse incentive effects. These incentive effects reduce the probability of success in case of debt centralization and thus c.p. lower expected returns and increase expected bankruptcy costs. Based on this trade-off, we now derive the optimal borrowing structure for the multinational corporation. The focus of our analysis is on creditor rights. For the following analysis, we only allow for parameter ranges resulting in positive net interest rates, thus $R_{F}^{i j} \geq 1$ and $R_{H}^{i j} \geq 1$ with $i, j=c, d{ }^{27}$

\section{Case 1: Equilibrium Without Empire-Building Tendencies}

First, we consider the situation without empire-building tendencies, i.e. $E=0$. In this case the following Proposition holds:

Proposition 2 Without empire-building tendencies, i.e. $E=0$, the borrowing structures $d d$ and cd are never optimal. The CEO of the multinational prefers a fully centralized borrowing structure when creditor rights are weak and the mixed borrowing structure dc when creditor rights are strong. The optimal borrowing structure is

1) $c c$ for $p<p_{1}$

2) $d c$ for $p \geq p_{1}$,

\footnotetext{
${ }^{27}$ This assumption excludes implausible situations in which investors are willing to pay the MNC for lending money. Investors would only want to pay for lending in the unrealistic situation that their expected pay-offs in case of bankruptcy were higher than debt repayments.
} 
with $p_{1}=\frac{(1-\alpha) Z}{\left[X+\left(3-2 q_{H}\right)(1-\alpha) Z\right] M}$.

Proof: See Appendix.

The intuition of the result is as follows: First of all, note that without empire-building tendencies, i.e. $E=0$, coinsuring subsidiary $H$ entails no adverse incentive effects on the foreign subsidiary manager $F$. Thus, centralizing the borrowing for subsidiary $H$ reduces expected bankruptcy costs and is the dominant borrowing strategy for subsidiary $H$. The fully decentralized borrowing structure $d d$ is always dominated by the mixed borrowing structure $d c$ with local borrowing in the foreign subsidiary $F$ and centralized borrowing in the subsidiary $H$. Similarly, the mixed borrowing structure $c d$ is always dominated by the fully centralized borrowing structure $c c$.

Consider the extreme case in which creditor rights are practically inexistent, i.e. $p=0$. In this situation, local borrowing entails no disciplining effect as even in case of insolvency the subsidiary will not be liquidated. Thus, decentralizing the borrowing of subsidiary $F$ would not enhance managerial effort but induce additional expected bankruptcy costs. So for $p=0$, decentralizing the debt of subsidiary $F$ cannot be optimal. Similarly, for very low levels of creditor rights, the increase in managerial incentives by decentralizing the borrowing for subsidiary $F$ is negligible as opposed to the reduction in expected bankruptcy costs which, due to the coinsurance effect, can be achieved by centralizing the borrowing for subsidiary $F$. Increasing creditor rights enhance the disciplining effect of local borrowing and thus the incentives of subsidiary $F$ manager. Thus, the opportunity cost of centralizing the borrowing for subsidiary $F$ increases with creditor rights and at $p_{1}$ dominates the coinsurance advantage of centralizing the borrowing for subsidiary $F$.

Case 2: Equilibrium with Weak Empire-Building Tendencies

For small tendencies of empire-building the following Proposition holds:

Proposition 3 When empire-building tendencies are weak, i.e. $0<E<\bar{E}$, the optimal borrowing structure is 
1) $c d$ for $p<p_{2}$

2) $c c$ for $p_{2} \leq p \leq p_{3}$,

3) $d c$ for $p>p_{3}$,

with $\bar{E}=\frac{\left(1-q_{H}\right)(1-\alpha)^{2} Z^{2}}{X^{2}+4\left(1-q_{H}\right)(1-\alpha) Z X+\left(3+3 q_{H}^{2}-7 q_{H}\right)(1-\alpha)^{2} Z^{2}} ; p_{2}=\frac{\left[X+\left(1-2 q_{H}\right)(1-\alpha) Z\right] E}{\left(1-q_{H}\right)(1-\alpha) Z M}$ and $p_{3}=\frac{(1-\alpha) Z\left(1-E q_{H}\right)}{\left[X+\left(3-2 q_{H}\right)(1-\alpha) Z\right] M}$.

Proof: See Appendix.

The intuition for the result is as follows: Again, when creditor rights are very weak, decentralizing the borrowing for subsidiary $F$ entails negligible incentive effects. Therefore, the borrowing for subsidiary $F$ should be undertaken centrally in order to exploit the coinsurance effect without any significant loss in incentives. However, decentralizing the borrowing for subsidiary $H$ entails some incentive effects for the manager of subsidiary $F$. Furthermore, with weak empire-building tendencies and weak creditor rights, the coinsurance of subsidiary $H$ by subsidiary $F$ is not very valuable. Hence, it is optimal to decentralize the borrowing for subsidiary $H$ in order to at least exploit the associated incentive effects, as these are relatively valuable with a low overall incentive level. With intermediate levels of creditor rights, however, the disciplining effect of bankruptcy is stronger; enhancing the incentives and probabilities of success associated both with local and centralized borrowing for subsidiary $F$. As now the part of incentives associated with empire-building becomes negligible but the coinsurance of subsidiary $H$ becomes more attractive, it is optimal to centralize $H$ as well and fully exploit the coinsurance effect. With very strong creditor rights, incentives due to the discipling effect of debt are very strong, and hence the probability of success for subsidiary $F$ is relatively large. This renders the coinsurance of subsidiary $F$ unnecessary but the coinsurance of subsidiary $H$ even more valuable, resulting in the optimal borrowing structure $d c$. 


\section{Case 3: Equilibrium with Strong Empire-Building Tendencies}

If empire-building tendencies are very strong, the following Proposition holds: ${ }^{28}$

Proposition 4 Consider the case when empire-building tendencies are strong, i.e. E > $\overline{\bar{E}}$. Then the optimal borrowing structures with very low and very strong creditor rights are mixed structures, $c d$ and dc respectively. For intermediate levels of creditor rights a fully decentralized borrowing structure is optimal. Thus,

1) $c d$ for $p<p_{4}$

2) $d d$ for $p_{4} \leq p \leq p_{5}$,

3) $d c$ for $p>p_{5}$,

with $\overline{\bar{E}}=\frac{(1-\alpha)^{2} Z^{2}}{X^{2}+\left(3-2 q_{H}\right)(1-\alpha) Z X+\left(3-3 q_{H}+q_{H}^{2}\right)(1-\alpha)^{2} Z^{2}} ; p_{4}=\frac{(1-\alpha) Z(1-E)}{\left[X+\left(2-q_{H}\right)(1-\alpha) Z\right] M}$ and

$p_{5}=\frac{\left[X+\left(1-q_{H}\right)(1-\alpha) Z\right] E}{(1-\alpha) Z M}$.

Proof: See Appendix.

For weak creditor rights the intuition is similar to the case with small empire-building tendencies: The CEO wants to exploit the incentive effects associated with decentralizing the borrowing for subsidiary $H$. These are now even more valuable, as empire-building tendencies are strong. As for weak creditor rights (decentralized) debt entails no major direct incentive effects, it is again optimal to exploit the coinsurance effect for subsidiary $F$ and hence choose the borrowing structure $c d$. For very strong creditor rights the intuition is also identical to the case with weak empire-building tendencies: As the incentives associated with the disciplining effect of debt are very high, exploiting this incentive effect by decentralizing the borrowing for subsidiary $F$ is optimal. As with the decentralization of the borrowing for subsidiary $F$, the probability of success for subsidiary $F$ increases,

\footnotetext{
${ }^{28}$ With intermediate levels of empire-building tendencies $\bar{E} \leq E \leq \overline{\bar{E}}$, the optimal borrowing structure will always be a mixed structure. For very low creditor rights the optimal structure is $c d$, with very high creditor rights, the optimal structure is $d c$. Note further that the comprehensive set of optimal borrowing structures $c d \rightarrow d d \rightarrow d c$ only exists if the benefits of empire building are not indefinitely high. In particular, for having a full set, the benefits of empire-building are limited above by $E \leq E^{*}=$ $\frac{(1-\alpha) Z M}{X+\left(1-q_{H}\right)(1-\alpha) Z}$ in order to ensure $p_{5} \leq 1$.
} 
the coinsurance of subsidiary $H$ becomes very valuable as well and is exploited by decentralizing the borrowing for subsidiary $H$.

But what changes for the intermediate level of creditor rights now? Again, stronger creditor rights increase the attractiveness of the coinsurance effect for subsidiary $H$ as well as the incentive effect of local borrowing for subsidiary $F$. With strong empire-building tendencies, however, local borrowing for subsidiary $H$ is very valuable as it allows fully exploiting the corresponding incentive effects for subsidiary $F$. This effect dominates the attractiveness of coinsuring subsidiary $H$ for a larger range of creditor rights. Thus, with strong empire-building tendencies, it is optimal to decentralize the borrowing for subsidiary $F$ for lower values of creditor rights before decentralizing the borrowing for subsidiary $H$ becomes attractive. Overall, a fully decentralized borrowing structure is optimal for intermediate levels of creditor rights.

Finally, an interesting implication for the optimal borrowing structure results from a closer look at the corner solutions of the managerial optimization problem (see Appendix). We summarize the findings in the following Corollary:

Corollary 1 Irrespective of creditor rights, a fully centralized borrowing structure is optimal both in the absence of and with very strong private benefits for the manager of subsidiary $F$.

The complete absence of private benefits, i.e. $M=E=0$, means that the manager does not derive any private benefits - neither from being the manager of the subsidiary nor from having additional funds under control. Thus, neither decentralizing the borrowing for subsidiary $F$ nor decentralizing the borrowing for subsidiary $H$ entails any incentive effects. The project in subsidiary $F$ fails for sure in $t=1 .^{29}$ Hence, the CEO of the multinational corporation centralizes the borrowing structure in order to optimally exploit the coinsurance effect. ${ }^{30}$ Similarly, in case of very strong private benefits of control, the

\footnotetext{
${ }^{29}$ Remember that the future profit $Z$ is generated irrespectively of the probability of success in $t=1$. Therefore, the NPV of the investment project can still be positive.

${ }^{30}$ Note that more precisely the CEO of the multinational corporation is indifferent between the borrowing structures $c c$ and $c d$. This is due to the fact that in our basic model set-up the probability of
} 
manager of subsidiary $F$ always exerts maximum efforts resulting in a probability of success of one under all borrowing structures. In this case, the manager's incentives are already strong enough with a fully centralized borrowing structure. Thus the CEO can perfectly well centralize the borrowing structure in order to optimally exploit the coinsurance effect without renouncing to managerial incentives. Surprisingly, even though we consider two completely different incentive situations, the optimal borrowing structure is the same and in both cases independent of the prevailing creditor rights.

\section{Creditor Rights and Interest Rates}

One interesting aspect we have not explicitly considered yet is the effect of creditor rights on equilibrium interest rates. Doing so allows us to derive empirically testable predictions, which can be used to verify the compliance of our model with real world data.

Proposition 5 Foreign affliates face lower interest rates for local borrowing if creditor rights are strong. That is $\frac{\partial R_{F}^{d c}}{\partial p} \leq 0$ and $\frac{\partial R_{F}^{d d}}{\partial p} \leq 0$.

Proof: See Appendix.

The intuition for this Proposition is as follows: Stronger creditor rights reduce the agency problem between the CEO and the manager of subsidiary $F$. This implies a higher effort level for the manager of subsidiary $F$ and hence higher probabilities of success for the investment project, which are reflected in the reduced interest rates. Desai et al. (2004) and Aggarwal and Kyaw (2004) find empirical evidence confirming this relationship.

\section{Comparative Statics}

In this section we investigate how firm and country characteristics influence the optimal borrowing structure. We consider the impact of profitability, of private benefits and of

success for subsidiary $F$ is equal to zero if the manager exerts no effort. In a richer model set-up allowing for a base-line probability of success, which can be realized independent of managerial effort, choosing the borrowing structure $c c$ would be unambiguously optimal. 
differences in the legal environment between the two countries in turn.

\section{Short-Term Vs. LONG-TERM Profitability}

How does the pay-off structure of the investment projects affect the degree of centralization of the borrowing structure? Do multinational corporations in industries with relatively high immediate pay-offs to investment, i.e. high values of $X$, e.g. in the music industry, prefer a more decentralized borrowing structure? Or should we rather expect multinationals with investment opportunities exhibiting very long pay-off periods, like infrastructure projects, which have a high continuation value $Z$, to prefer a more centralized borrowing structure? We provide the answer in the following two Propositions:

Proposition 6 A higher first period profit in case of success $X$ increases the parameter range for which a more decentralized borrowing structure is preferred. In particular, $\frac{\partial p_{1}}{\partial X} \leq$ $0, \frac{\partial}{\partial X}\left(p_{3}-p_{2}\right) \leq 0 \wedge \frac{\partial}{\partial X}\left(p_{5}-p_{4}\right) \geq 0$ and $\frac{\partial \bar{E}}{\partial X} \leq 0, \frac{\partial \bar{E}}{\partial X} \leq 0$.

Proof: See Appendix.

Proposition 7 A higher future value of the firm $Z$ increases the parameter range for which a more centralized borrowing structure is preferred. In particular, $\frac{\partial p_{1}}{\partial Z} \geq 0, \frac{\partial}{\partial Z}\left(p_{3}-\right.$ $\left.p_{2}\right) \geq 0 \wedge \frac{\partial}{\partial Z}\left(p_{5}-p_{4}\right) \leq 0$ and $\frac{\partial \bar{E}}{\partial Z} \geq 0, \frac{\partial \overline{\bar{E}}}{\partial Z} \geq 0$.

Proof: See Appendix.

Consider Proposition ?? first: A higher first period profit $X$ makes the success of a subsidiary more valuable. Thus, it is more attractive to provide the manager of subsidiary $F$ with stronger incentives by decentralizing the borrowing structure. This is reflected both in the reduced optimality range for $c c$ in the cases 1 and 2 (without and with weak empire-building tendencies), and in the increased optimality range for $d d$ in case 3 (with strong empire-building tendencies). Additionally, as compared to case 2, case 3 becomes relatively more likely.

In contrast, consider Proposition ??: An increase in the future value of the investment project $Z$ increases the attractiveness of realizing the coinsurance effect as there is more 
at stake if a borrowing unit goes bankrupt. Centralizing the borrowing structure has a negative impact on the probability of success for subsidiary $F$. However, we can show that this adverse effect is outweighed by the positive effect of coinsurance by centralizing the borrowing structure. Hence, in cases 1 and 2 the optimality range for $c c$ increases, in case 3 the optimality range for $d d$ decreases. Furthermore, as compared to case 3 , case 2 becomes relatively more likely.

To summarize, we can say that while first period profits increase the relevance of the incentive effect, future profits - or rather the threat of losing them - increase the relevance of the coinsurance effect.

\section{The Private Benefits of Control}

Intuitively we would expect that the private benefits of control $-E$ and $M$ - have very clear cut and similar effects on the borrowing structure. Both types of private benefits should increase the attractiveness of a decentralized borrowing structure as incentives become more important: An increase in $M$ implies stronger direct private benefits of being the manager. Therefore, we would expect an increase in the attractiveness of decentralized borrowing for subsidiary $F$ in order to exploit these incentives. An increase in $E$ implies stronger indirect benefits of empire-building. Thus, we would expect an increase in the attractiveness of decentralized borrowing for subsidiary $H$ in order to exploit these incentives. Furthermore, we would not expect that an increase in $M$ influences the borrowing structure for subsidiary $H$. Similarly, we would not expect that an increase in $E$ influences the borrowing structure for subsidiary $F$. But this is not what we find.

Proposition 8 Stronger empire-building tendencies E increase (decrease) the parameter range for which a decentralized (centralized) borrowing structure is optimal. However, higher benefits of control $M$ increase the parameter range for which the mixed debt structure dc is preferred as compared to all other borrowing structures. That is for $E$ : $\frac{\partial p_{2}}{\partial E} \geq 0$,

$\frac{\partial p_{3}}{\partial E} \leq 0$ and $\frac{\partial p_{4}}{\partial E} \leq 0 \frac{\partial p_{5}}{\partial E} \geq 0$ and for $M: \frac{\partial p_{3}}{\partial M}<\frac{\partial p_{2}}{\partial M} \leq 0$ and $\frac{\partial p_{5}}{\partial M}<\frac{\partial p_{4}}{\partial M} \leq 0$.

Proof: See Appendix. 
The direct incentive effects are as expected. If the benefits of being a manager $M$ increase, decentralizing subsidiary $F$ becomes more attractive as an increase in $M$ implies a higher incentive effect associated with the decentralization of the foreign managers own subsidiary F. A similar rationale holds with respect to the private benefits associated with empire-building $E$. In this case, decentralizing subsidiary $H$ becomes more attractive when the associated benefits $E$ are high. Coinsuring subsidiary $H$ would weaken the incentives of the subsidiary manager $F$ too much. However, there is a further indirect effect associated with an increase in the private benefits: Higher private benefits, i.e. higher values of $E$ and $M$, both c.p. increase the probability of success $q_{F}$ for subsidiary $F$. This in turn influences the attractiveness of the coinsurance effect. As $q_{F}$ increases, coinsuring subsidiary $H$ in the parental country becomes more attractive whereas the coinsurance of subsidiary $F$ becomes less attractive. This indirect effect leads to the asymmetric results laid down in Proposition ??.

\section{National Differences in the Legal Environment}

So far, we focused on multinational corporations and/or business groups operating in countries with similar legal environments. Naturally, many multinationals have subsidiaries in countries with very different legal environments. In this final part of the section, we therefore introduce differences in the legal environment and investigate how these affect the optimal borrowing structure of multinational corporations. In our model, the legal environment is reflected by two parameters: First of all, creditor rights, captured by the parameter $p$, are core to the legal environment of a country (see introduction). Secondly, the legal environment comprehends also the design and the efficiency of the bankruptcy process. Thus, the associated dissipative costs $(1-\alpha)$ will be shaped by the prevailing legal environment.

In the following, we discuss the impact of both aspects on the optimal borrowing structure of a multinational corporation.

Consider the bankruptcy process first. Without differences in the bankruptcy process, i.e. identical values of $\alpha$ for the two countries, bankruptcy costs reflected by $(1-\alpha)$, 
influence the optimal borrowing structure in exactly the same way as future profits $Z$. Both higher values for $Z$ or lower values of $\alpha$ increase expected losses from bankruptcy and therefore increase the attractiveness of avoiding bankruptcy and hence of a more centralized borrowing structure. The more interesting question however is, how differences in the efficiency of the bankruptcy process between the parental and the foreign country affect the optimal borrowing structure. To answer this question we introduce country specific parameters $\alpha_{H}$ and $\alpha_{F}$ for the (in-)efficiencies of the bankruptcy process in the home country of the parental company and the foreign country and investigate the effects on expected profits. Our results are summarized in the following Proposition:

Proposition 9 With $\left.\frac{\partial E \pi(c c)}{\partial \alpha_{F}}\right|_{\alpha_{F}=\alpha_{H}=\alpha}=\left.\frac{\partial E \pi(c d)}{\partial \alpha_{F}}\right|_{\alpha_{F}=\alpha_{H}=\alpha}=0$

$\leq\left.\frac{\partial E \pi(d d)}{\partial \alpha_{F}}\right|_{\alpha_{F}=\alpha_{H}=\alpha} \leq\left.\frac{\partial E \pi(d c)}{\partial \alpha_{F}}\right|_{\alpha_{F}=\alpha_{H}=\alpha}$, a decrease in the bankruptcy costs $\left(1-\alpha_{F}\right)$ increases the attractiveness of decentralizing the borrowing for subsidiary $F$ in the foreign country. This increase is especially pronounced for the mixed borrowing structure dc.

Proof: See Appendix.

The intuition is straightforward: A lower bankruptcy inefficiency in the foreign country $F$, i.e. a higher value for $\alpha_{F}$, is associated with a lower downside risk of decentralized borrowing in $F$. The loss in the future firm value in case of bankruptcy is lower, and so the CEO prefers to decentralize the borrowing for subsidiary $F$ in order to better exploit the incentive effect. Since under $d c$ subsidiary $H$ is coinsured by subsidiary $F$, there are positive spillover effects of the better legal environment in country $F$. The intuition therefore is as follows: As coinsuring subsidiary $H$ entails adverse incentive effects for the subsidiary $F$ manager and hence lower probability of success for subsidiary $F$, the gains of a reduced cost of bankruptcy are larger. Note however, that the results are only driven by the reduced attractiveness of the coinsurance effect of centralized borrowing for subsidiary $F$. The (in-)efficiency of the bankruptcy system does not affect managerial incentives but only the loss in future value in case of bankruptcy. 
Let us now turn to creditor rights. A priori, we would expect creditor rights to have a strong direct effect on expected profits. Surprisingly, though, this is not the case.

Proposition 10 Differences in the creditor rights do not directly affect expected profits under any borrowing structure. However, due to the incentive effect, the attractiveness of borrowing structures with decentralized borrowing for subsidiary F increases with higher creditor rights in country $F$ as compared to the parental company's home country, i.e. $\left.\frac{\partial E \pi(c d)}{\partial p_{F}}\right|_{p_{F}=p_{H}=p}=\left.\frac{\partial E \pi(c c)}{\partial p_{F}}\right|_{p_{F}=p_{H}=p}=0 \leq\left.\frac{\partial E \pi(d d)}{\partial p_{F}}\right|_{p_{F}=p_{H}=p} \leq\left.\frac{\partial E \pi(d c)}{\partial p_{F}}\right|_{p_{F}=p_{H}=p}$.

Proof: See Appendix.

The intuition is as follows: Differences in the borrowing structure directly influence expected bankruptcy costs of the multinational corporation. However, they also affect the interest rates external investors require. From an ex-ante perspective, as investors are fully competitive, these two effects exactly cancel each other out. The only remaining impact of creditor rights is on the incentives of the subsidiary manager $F$. These of course only depend on the creditor rights prevailing in the country of origin of the debt. The overall effect under $d c$ is stronger than under $d d$. This is due to the fact that the same increase in incentives has a stronger effect on expected bankruptcy costs if subsidiary $H$ is coinsured.

\section{Empirical Hypotheses}

In this final section, we highlight the main empirical implications of our model.

As we have shown in our analysis, creditor rights are key in determining the optimal borrowing structure of a MNC. ${ }^{31}$ The first hypothesis we derive relates the borrowing structure of the MNC's foreign affiliates to the strength of creditor rights:

\footnotetext{
${ }^{31}$ Note, however, that with creditor rights we refer to effective creditor rights. As also Safavian and Sharma (2007) verify empirically, it is not only the creditor-friendliness of the laws that determines the effective strength of creditor rights in a country but also the enforcement of the laws. This is part of our model, as only an effective creditor-orientation constitutes a credible threat of liquidation.
} 
Hypothesis 1 Subsidiaries of MNCs in countries with weaker creditor rights will rely more on centralized borrowing by the parental company, thus borrow less decentrally.

This hypothesis reflects the findings of Desai et al. (2004). The authors find evidence that foreign affiliates' borrowing costs for external finance are higher in countries with weak creditor rights. They furthermore show that foreign affiliates in countries with weak creditor rights use internal capital markets in order to substitute for external debt. As the authors reckon, weak creditor rights might give rise to an agency problem as they reduce the creditor's incentive to avoid bankruptcy. Internal capital markets can thus be used "to fund subsidiaries in jurisdictions providing weak creditor rights, drawing on capital from operations located in countries offering strong creditor rights" (Desai et al. (2004), p. 2456). These are exactly the forces at work in our model. Furthermore, taking into account that financial institutions are better developed with better legal protection (Levine (1999)), the hypothesis is also in line with the findings of Kang et al. (2004) of a positive relationship between the extent of foreign affiliates' local borrowing and financial market development.

Consider the dissipative costs associated with the bankruptcy system next. In our model, bankruptcy costs are captured by the parameter $(1-\alpha)$. As higher bankruptcy costs increase expected losses from bankruptcy, we derive the following empirical hypothesis:

Hypothesis 2 High bankruptcy costs lead to a more centralized borrowing structure.

Even though in our analysis bankruptcy costs are modeled in a rather stylized way - as they simply consist of the costs associated with financial distress, and not of actual liquidation - the above relationship should even be reinforced if we included actual costs of liquidation.

With respect to industry-specific characteristics we can derive the following hypothesis: 
Hypothesis 3 MNCs operating in industries with longterm pay-off periods prefer a centralized borrowing structure, whereas MNCs in industries with shortterm pay-off periods prefer a decentralized borrowing structure.

From Propositions ?? and ?? we know that immediate profits and future profits have completely opposing effects. For MNCs with higher immediate profits (shortterm pay-off periods) the incentive effect is the driving force for their borrowing structure. In contrast, for firms with higher future profits (longterm pay-off periods) the coinsurance effect is very valuable. These effects are reflected in the above hypothesis.

Finally, a more indirect relationship that can be established between the legal environment and the borrowing structure is related to the private benefits of control. As for example Dyck and Zingales (2004) empirically verify: strong "legal institutions are strongly associated with lower levels of private benefits" (Dyck and Zingales (2004), p. 582). ${ }^{32}$ This holds in particular for regulations regarding the transparency of firms. Thus, we expect the general level of private benefits of control to be relatively lower in countries with a more effective and transparent legal environment. Combining this relationship with our insights with respect to managerial private benefits, $M$ and $E$, we can derive the following final hypothesis:

Hypothesis 4 MNCs with foreign affiliates in countries with relatively low transparency requirements and hence higher private benefits of control decentralize their affiliates' borrowing.

\section{Conclusion}

In this paper we developed a framework for understanding the debt allocation process within multinational corporations. In our analysis we showed that the debt structure

\footnotetext{
${ }^{32}$ Even though the focus of their analysis is on private benefits controlling shareholders enjoy, the general findings should at least be partially applicable to the private benefits a non-owner subsidiary manager enjoys.
} 
within multinationals matters beyond tax issues - a fact that had almost been completely neglected in the literature so far. In particular, we highlighted that the legal environment is key in determining the degree of debt centralization within a MNC. However, as our analysis suggests, different aspects of the legal environment have differing effects on the borrowing structure.

Although very stylized, our model and results do reflect the existing empirical findings related to multinational finance and creditor rights. While we provide a rationale for mixed borrowing structures, we demonstrate how the trade-off between incentive problems in internal capital markets and coinsurance determines the optimal borrowing structure. Our analysis highlights the relevance of creditor rights for a multi-entity firm's capital structure in general and for multinational corporations in particular. Differences in the legal environment induce a bias of the debt allocation towards the country with a better legal environment, i.e. stronger creditor rights and lower bankruptcy costs. A major contribution of our paper is to highlight the importance of a comprehensive view on multinationals' borrowing decision due to feedback effects on internal capital markets an aspect that current research on MNC finance did not focus on yet.

A more comprehensive model would endogenize the incentive problems of the home subsidiary as well. The basic trade-off of our model would not be affected but there may be room for reinforcing incentive effects between the subsidiaries. This must be left to future research. Further questions to be addressed in future research relate to the effect of creditor rights on several aspects of multinational finance. An extension of our work could incorporate the choice between equity and debt into a model of multinational finance. A particularly interesting question is how the legal environment affects the multinational's choice between internal debt, i.e. parental borrowing for the subsidiaries, and internal equity. Another interesting aspect which needs further empirical investigation is a differentiated analysis of the effect of creditor rights on the different aspects of the insolvency regime, for example also the actual liquidation of insolvent firms. 


\section{Bibliography}

Acharya, V. V., Sundaram, R. K., and John, K. (2005). Cross-Country Variations in Capital Structures: The Role of Bankruptcy Codes. CEPR Discussion Paper, No. 4916.

Aggarwal, R. and Kyaw, N. A. (2004). Internal Capital Markets and Capital Structure Choices of U.S. Multinationals' Affiliates. FMA 2005 Chicago Conference Paper.

Aghion, P. and Bolton, P. (1992). An Incomplete Contracts Approach to Financial Contracting. Review of Economic Studies, 59(3): 473-494.

Altman, E.I. (1984). A Further Empirical Investigation of the Bankruptcy Cost Question. Journal of Finance, 39(4): 1067-1089.

Berkovitch, E., Israel, R. and Tolkowsky, E. (2006). The Boundaries of the Firm: The Choice between Stand-Alone and Integrated Firms. Journal of Economics and Management Strategy, 15(4): 821-851.

Bianco, M. and Nicodano, G. (2006). Pyramidal Groups and Debt. European Economic Review, 50(4): 937-961.

Boot, A. W. A. and Schmeits, A. (2000). Market Discipline and Incentive Problems in Conglomerate Firms with Application to Banking. Journal of Financial Intermediation, 9(3): 240-273.

Brusco, S. and Panunzi, F. (2005). Reallocation of Corporate Resources and Managerial Incentives in Internal Capital Markets. European Economic Review, 49(3): 659-681.

Burgman, T. A. (1996). An Empirical Examination of Multinational Corporate Capital Structure. Journal of International Business Studies, 27(3): 553-570.

Chowdhry, B. and Coval, J. D. (1998). Internal Financing of Multinational Subsidiaries: Debt vs. Equity. Journal of Corporate Finance, 4(1): 87-106. 
Chowdhry, B. and Nanda, V. (1994). Financing of Multinational Subsidiaries: Parent Debt vs. External Debt. Journal of Corporate Finance, 1(2): 259-281.

Claessens, S., Djankov, S., and Nenova, T. (2000). Corporate Risk around the World. The World Bank Policy Research Working Paper Series, No. 2271.

Claessens, S. and Klapper, L. F. (2005). Bankruptcy around the World: Explanations of Its Relative Use. American Law and Economics Review, 7(1): 253-283.

Demirguc-Kunt, A. and Maksimovic, V. (1998). Law, Finance, and Firm Growth. Journal of Finance, 53(6): 2107-2137.

Demirguc-Kunt, A. and Maksimovic, V. (1999). Institutions, Financial Markets, and Firm Debt Maturity. Journal of Financial Economics, 54(3): 295-336.

Desai, M. A., Foley, C. F., and Hines, J. R. (2004). A Multinational Perspective on Capital Structure Choice and Internal Capital Markets. Journal of Finance, 59(6): 2451-2487.

Desai, M. A., Foley, C. F. and Hines, J. R. (2008). Capital Structure with Risky Foreign Investment. Journal of Financial Economics, 88(3): 534-553.

Dewatripont, M. and Tirole, J. (1994). A Theory of Debt and Equity: Diversity of Securities and Manager-Shareholder Congruence. The Quarterly Journal of Economics, 109(4): 1027-1054.

Djankov, S., Hart, O., McLiesh, C., and Shleifer, A. (2006). Debt Enforcement around the World. ECGI - Finance Working Paper, No. 147/2007.

Doukas, J. A. and Pantzalis, C. (2003). Geographic Diversification and Agency Costs of Debt of Multinational Firms. Journal of Corporate Finance, 9(1): 59-92.

Dyck, A. and Zingales, L. (2004). Private Benefits of Control: An International Comparison. Journal of Finance, 59(2): 537-600. 
Errunza, V. R. (1979). Financing MNC Subsidiaries in Central America. Journal of International Business Studies, 10(2): 88-92.

Fatemi, A. M. (1988). The Effect of International Diversification on Corporate Financing Policy. Journal of Business Research, 16(1): 17-30.

Faure-Grimaud, A. and Inderst, R. (2005). Conglomerate Entrenchment Under Optimal Financial Contracting. American Economic Review, 95(3): 850-861.

Gautier, A. and Heider, F. (2002). The Benefit and Cost of Winner-Picking: Redistribution vs. Incentives. University of Bonn, Econ Discussion Papers, bgse31_2002.

Gertner, R. H., Scharfstein, D., and Stein, J. (1994). Internal versus External Capital Markets. The Quarterly Journal of Economics, 109(4): 1211-1230.

Giannetti, M. (2003). Do Better Institutions Mitigate Agency Problems? Evidence from Corporate Finance Choices. Journal of Financial and Quantitative Analysis, 38(1): 185212.

Gopalan, R., Nanda, R., and Seru, A. (2007). Affiliated Firms and Financial Support: Evidence from Indian Business Groups. Journal of Financial Economics, 86(3): 759-795.

Grossman, S. J. and Hart, O. D. (1982). Corporate Financial Structure and Managerial Incentives. In McCall, J., Editor, The Economics of Uncertainty, Pages 107-140, Chicago. University of Chicago Press.

Hart, O. D. and Moore, J. (1995). Debt and Seniority: An Analysis of the Role of Hard Claims in Constraining Management. American Economic Review, 85(3): 567-585.

Hodder, J. E. and Senbet, L. W. (1990). International Capital Structure Equilibrium. Journal of Finance, 45(5): 1495-1516.

Hooper, V. (2002). Multinational Financing Strategies in High Political Risk Countries. University of New South Wales, School of Banking and Finance, Working Paper. 
Huizinga, H. P., Laeven, L. and Nicodème, G. (2008). Capital Structure and International Debt Shifting. Journal of Financial Economics, 88(1): 80-118.

Inderst, R. and Laux, C. (2005). Incentives in Internal Capital Markets: Capital Constraints, Competition, and Investment Opportunities. RAND Journal of Economics, 36(1): 215-228.

Inderst, R. and Müller, H. M. (2003). Internal versus External Financing: An Optimal Contracting Approach. Journal of Finance, 58(3): 1033-1062.

Kang, H. G., Lehmann, A. and Sayek, S. (2004). Multinational Affiliates and Local Financial Markets. IMF Working Papers, No. 04/107.

Kesternich, I. and Schnitzer, M. (2007). Who Is Afraid of Political Risk? Multinational Firms and Their Choice of Capital Structure. CEPR Discussion Papers, No. 6468.

Laeven, L and Majnoni, G. (2005). Does Judicial Efficiency Lower the Cost of Credit? Journal of Banking \& Finance, 29(7): 1791-1812.

La Porta, R., de Silanes, F. L., Shleifer, A., and Vishny, R. W. (1997). Legal Determinants of External Finance. The Journal of Finance, 52(3): 1131-1150.

La Porta, R., de Silanes, F. L., Shleifer, A., and Vishny, R. W. (1998). Law and Finance. Journal of Political Economy, 106(6): 1113-1155.

Lee, K. C. and Kwok, C. C. Y. (1988). Multinational Corporations vs. Domestic Corporations: International Environmental Factors and Determinants of Capital Structure. Journal of International Business Studies, 19(2): 195-217.

Levine, R. (1999). Law, Finance and Economic Growth. Journal of Financial Intermediation, 8(1-2): 8-35.

Lewellen, W. G. (1971). A Pure Financial Rationale for the Conglomerate Merger. Journal of Finance, 26(2): 521-537. 
Li, D. D. and Li, S. (1996). A Theory of Corporate Scope and Financial Structure. Journal of Finance, 51(2): 691-709.

Mittoo, U. R. and Zhang, Z. (2005). The Capital Structure of Multinational Corporations: Canadian versus U.S. Evidence. FMA 2005 Chicago Conference Paper.

Noe, T. H. (2000). Creditor Rights and Multinational Capital Structure. Tulane University, Working Paper.

Rajan, R. G., Servaes, H. and Zingales, L. (2000). The Cost of Diversity: The Diversification Discount and Inefficient Investment. Journal of Finance, 55(1): 35-80.

Safavian, M. and Sharma, S. (2007). When Do Creditor Rights Work? Journal of Comparative Economics, 35(3): 484-508.

Stein, J. (1997). Internal Capital Markets and the Competition for Corporate Resources. Journal of Finance, 52(1): 111-133.

Stein, J. (2003). Agency, Information and Corporate Investment. In G.M. Constantinides, M. H. and Stulz, R. M., Editors, Handbook of the Economics of Finance, Volume 1A, Pages 111-165. Elsevier North-Holland.

Wright, F. W., Madura, J. and Wiant, K. J. (2002). The Differential Effects of Agency Costs on Multinational Corporations. Applied Financial Economics, 12(5): 347-359.

\section{Appendix}

The Appendix can be found under http://www.en.compecon.vwl.lmu.de/research/download/. 